\title{
Research on Development Trend and Countermeasures of Xuzhou Logistics Industry
}

\author{
Xu-dong $\mathrm{He}$ \\ School of Management \\ Xuzhou Institute of Technology \\ Jiangsu, China \\ 289031610@qq.com
}

\author{
Yuan-Yuan Zhang \\ School of Management \\ Xuzhou Institute of Technology \\ Jiangsu, China \\ guojimaoyi20030421@126.com
}

\begin{abstract}
Taking Xuzhou logistics development as an example, the paper analyzes opportunities and challenges of current logistics industry, expounds the current situation of logistics development, discusses problems and shortcomings, points out the future trends of development of Xuzhou logistics. For the above problems, we put forward management suggestions and strategies to promote the development of Xuzhou logistics.
\end{abstract}

Keywords-Logistics industry; Development trend; Logistics innovation; Countermeasure

\section{INTRODUCTION}

At present, China's economy is in a special stage of growth rate shifting period. New changes have taken place in the industrial structure, and service industries, especially producer services, have been given priority support. It is of strategic importance to speed up the development of modern logistics for promoting economic restructuring, enhancing industrial development vitality, optimizing urban investment environment and increasing competitiveness.

\section{A. Development opportunities}

China has deployed implementing strategies such as "the Belt and Road Initiatives", the Yangtze River economic belt, etc. Strategic adjustment of the economic pattern will promote cross regional allocation of logistics resources, promote the formation of regional logistics integration pattern. In order to fully connect with strategy of "the Belt and Road Initiatives", Xuzhou municipal government proposed to accelerate the construction of the modern industrial system, which taking the advanced manufacturing industry as the main subject, strategic emerging industry as the forerunner, modern service industry as the support, modern agriculture as the foundation [1]. At the same time, the sustained growth of China's economy, the adjustment of economic structure, the transfer of industrial gradient, the acceleration of urbanization and upgrading of consumption structure will bring new opportunities for the development of the logistics industry.

\section{B. Facing challenges}

The development strategy of "the Belt and Road Initiatives" brings forward new requirements for the economic development of Xuzhou. We should accelerate integration into "the Belt and Road Initiatives" construction, strengthen infrastructure construction of logistics channel at three levels of domestic, international and intercity, so as to adapt to new demands for logistics of economic development and industrial layout. With the adjustment of Xuzhou's economic structure, the demand for business logistics and cold chain logistics continue to increase. The high-end equipment manufacturing requires modern manufacturing logistics service to support. Ecommerce and network consumption have developed rapidly, new logistics technologies and logistic concepts have been emerging. Therefore, it is urgent to establish a perfect logistics distribution system.

\section{DEVELOPMENT STATUS}

\section{A. The overall size of logistics industry continues to grow}

Logistics revenue increased from 109 billion Yuan in 2011 to 208 billion Yuan in 2015 by the average annual growth rate of $17.6 \%$.The total volume of social logistics increased from 971 billion Yuan to 1 trillion and 559 billion Yuan by average rate of $12.56 \%$. Added value of logistics industry increased from 26 billion Yuan to 42 billion Yuan by the average annual growth rate of $12.93 \%$.

\section{B. Logistics service ability has been improved significantly}

Highway, waterway transportation, air transportation railway and multimodal transportation have been developed rapidly. The logistics service ability has been remarkably improved. Traditional warehousing and transportation services are transformed to third party logistics and supply chain management services. Electricity supplier logistics, cold chain logistics and other specialized social service capabilities have been significantly enhanced. New modes of business such as road port and joint distribution have been emerging. 


\section{Logistics agglomeration effects continue to increase}

Relying on the land transportation hubs, the Beijing Hangzhou canal ports, airports, economic development zones, industry agglomeration and farmer's wholesale markets, a number of functional integrated logistics parks and logistics bases have been built. Logistics agglomeration effect has appeared rapidly.

\section{Logistics infrastructure has been continuously improved}

The total mileage of Xuzhou highway reaches 16,300 kilometers, and the skeleton road network is basically formed. The trunk line of the railway runs 396 kilometers, forming a "ten" type of double million ton railway passage. The total length of the channel reaches $1033 \mathrm{~km}$, and a tree shaped channel network with Beijing Hangzhou, the Grand Canal as the aorta and other connected channels has been preliminarily formed.

\section{E. Development environment has been improved gradually}

Actively coordinating with "The Belt and Road" strategy, local government has formulated a series of relevant policies and measures to support the development of logistics industry. We should strengthen "online and offline" synchronous development, build logistics "platform economy", reform all types of markets, encourage specialized markets to focus on the logistics park and promote the establishment of multimodal transportation alliance.

\section{EXISTING PROBLEMS}

\section{A. Lack of synergy between logistics and Industry}

Being lack of logistics service in the industry gathering area, the driving ability of logistics appears insufficient. Business logistics and agricultural products logistics mainly depend on the wholesale market, the degree of specialization being not enough. There is a lack of modern logistics belts which are closely linked with commercial agglomeration zone and agricultural products logistics agglomeration zone.

\section{B. Agglomeration effect is insufficient}

Logistics space layout is lack of hierarchy and the system division of logistics agglomeration area, Logistics Park, logistics center and distribution station is not clear. The logistics node classification is not obvious and the phenomenon of repeated construction is very seriously. Although the number of logistics parks (centers) is large, but agglomeration effect is insufficient because of the dispersion of the logistics industry.

\section{Logistics enterprises lack brand effects}

There are too many logistics enterprises generally with small scale and low degree of modernization, informationization and specialization. Not only influential large-scale modern comprehensive logistics base, but also cross-regional or national logistics enterprises is scarce. Being lower logistics quality and logistics benefits generally, logistics enterprises lack brand effects obviously.

\section{Multimodal transport lacks systematic and pivot effect}

The development of logistics nodes are not balanced, and the multimodal transport system has not been formed. The building process of multimodal transport public information platform is slow, and the carrier construction lacks effective guidance. Inter-city railway is still blank, the channel network formation rate is low, and the urban expressway system lacks stable layout scheme.

\section{E. Logistics environment lacks of supporting effect}

The construction of logistics standardization lags and technical service is not standardized. The logistics statistics system has not really been established. Insufficient investment of logistics technology can not effectively support the development of the logistics industry. Being lack of effective logistics policies and regulations to guide and support the orderly and rapid development of the logistics industry, it is urgent to strengthen support roles of the government.

\section{DEVELOPMENT TRENDS}

\section{A. Industry linkage and integration is the internal power of the sustainable development of modern logistics}

Industrial logistics is still the biggest demand of the logistics industry, and it is also the largest potential for the upgrading of logistics industry in the future. With the upgrading of manufacturing industry and changes of trade mode, the logistics industry will further deepen linkage and integration of the industry [2]. Linkage between manufacturing and logistics can effectively reduce the inventory, accelerate access time and reduce the cost of business operations. Linkage between trade market and logistics industry can realize the distribution of circulation commodities. Linkage between mobile Internet and e-commerce can promote the integration of the logistics industry and the financial industry.

\section{B. Improving quality of service is the main means to improve the competitiveness of logistics enterprises}

Improving the service quality of logistics enterprises can increase the satisfaction of users and operating benefits of enterprises. Shortening logistics time, improving the reliability of distribution, improving the quality of distribution personnel and paying attention to the service mode of logistics complaint are the traditional ways to improve the service quality of logistics enterprises. With the improvement of logistics technology, equipment, operation levels and organization mode, the competition in the logistics market becomes more and more fierce, and improving service quality will become an important means for logistics enterprises to fight for market share. 


\section{Developing livelihood logistics based on urban and rural joint distribution is an important support for expanding logistics demand}

Rapid development of e-commerce market has put forward new requirements for logistics. Optimizing network, promoting management and serving experience of city distribution have been the focus of competition in e-commerce enterprises. With promotion of urbanization, the short board of urban distribution has become prominent, but it also become a new opportunity for the future development of the logistics. In order to open up the logistics "micro-circulation" to solve the "last mile" problem, we should develop the city community and rural logistics, improve the network system of joint distribution, optimize urban distribution modes, and establish a convenient, efficient, standardized and orderly city distribution service system to create new advantages of competition.

\section{Integration of logistics factors is an inevitable way to build intensive competitive advantages}

With formation of logistics infrastructure network, the problems of transportation capacity and storage capacity constraining the development of industry has been alleviated gradually, which lays the foundation for integrating the dispersed resources through the logistics platform and realizing transformation of the development model. We should effort to strengthen infrastructure construction, improve comprehensive transportation capacity of the road network, integrate upstream and downstream resources of manufacturing industry, build a gathering platform of logistics parks to drive small and medium logistics enterprises to settle in [3]. It is necessary for various types of logistics platform to speed up network opening and agglomerate all kinds of logistics factors, so as to build new competitive advantages of logistics.

\section{E. Regional logistics development is an innovative driving power to promote open economy}

Regional economic development has provided the necessary logistics demand market for the development of regional logistics. Promoting the coordinated development of regional logistics, is not only the inevitable requirement to respond development strategies of regional economy, but also the innovative driving force to promote open economy in Xuzhou. Using regional cooperation platform such as Huaihai Economic Zone, Four Province Logistics Corridor to establish regional cooperation mechanism to promote the integration of regional logistics is benefit for breaking the regional compartmentalization defects. We should take advantages of regional logistics information platforms logistics enterprise alliance, cross-regional multimodal transport construction and other means to promote quick circulation of regional logistics resources and sustainable development of the logistics industry.

\section{F. Transition from logistics service providers to supply chain providers is an inevitable trend}

Along with the implementation of "going out" strategy in manufacturing industry, we will have to face the globalized procurement of raw materials, globalized productivity layout, globalized marketing requirements. So we should strengthen the layout and control of key logistics node and logistics resource, the implementation of the integration of supply chain management, implement the integrated supply chain management, achieve the global allocation of resources, and build a win-win strategic partnership with the global stakeholders, so as to control the leading power of the supply chain. Logistics enterprises should focus on expanding the logistics service function, transforming from "logistics service provider" to "supply chain provider", and enhancing the sustainable competitiveness of enterprise [4].

\section{G. Logistics intelligence is an innovative model to reform the traditional logistics industry}

At present, the vigorous development of the new information technology, such as Internet of things, cloud computing, mobile Internet and others, is driving the transformation of China's intelligent logistics. Its increasing popularity and wide application will profoundly change the mode of logistics resource allocation, and provide a powerful impetus for logistics industry to achieve innovation driven development. We should rely on the advantages of manufacturing enterprises and logistics carriers to integrate logistics related social resources, use the Internet, internet of things, cloud computing, big data, artificial intelligence and other technologies to build intelligent logistics. By means of technological transformation and upgrading of equipment, we should improve the levels of logistics informatization, mechanization and automation, increase unit output efficiency and innovate the logistics service mode.

\section{Countermeasures AND SugGestions}

\section{A. Effort to build major modern logistics systems}

Taking the integration of logistics industry and manufacturing industry as the foundation, constructing the key logistics node of manufacturing industry as the handle, strengthening integration service function of the supply chain as the focus, we should vigorously promote the extension of manufacturing logistics towards specialization and high-end value chain, make great efforts to improve supporting capability of manufacturing logistics serving for high-end manufacturing and to create efficient, intensive and integrated supply chain system.

Taking "quick, convenient, professional and green" as the guide, serving consumer demand as the goal, we should expand modern logistics and upgrade the traditional logistics, develop the third party logistics, improve the standardization and informationization level of commercial logistics, build a regional logistics highland. We should strengthen effective links between urban and rural distribution, promote the coordinated development of commercial and logistics, logistics and e-commerce, promote domestic and international business 
logistics interconnected, so as to create a convenient, smooth and integrated trade logistics system.

Taking the vision of green development for the country and the people as the goal, we should vigorously develop the third party and the fourth party agricultural products logistics, improve standardization and informatization levels of agricultural logistics, accelerate the integration of logistics resources, create a regional agricultural products logistics gathering. We should give full play to the role of government guiding and market leading, focus on forming multilevel logistics service network of cold chain logistics and normal temperature logistics of agricultural products, so as to create a green, integrated agricultural products logistics system.

\section{B. Focus on the implementation of major logistics projects}

\section{1) Multimodal transport project}

Based on the national major coastal ports, the new Eurasian Continental Bridge, and comprehensive transportation network of Xuzhou city, We will focus on establishing a multimodal transport system linking the coastal ports along the river and radiating the Midwestern regions. Taking Lianyungang port as the main access to the sea, we will establish the "dry port" in Xuzhou in order to extend the service function of Lianyungang port. By using the Beijing Hangzhou canal, Beijing Shanghai railway and high-grade highway network to link the Yangtze River Delta and the Yangtze River, we should develop the multimodal transport of coal, minerals, building materials.

\section{2) Logistics park project}

Combined with the regional transportation advantages, leading industry of Xuzhou, economic ties and logistics demand of Huaihai Economic Zone, reasonable layout of logistics parks will be designed. Relying on the railway station and inland area, we will develop freight hub logistics park, port service logistics park and comprehensive service logistics park. Relying on industrial parks, develop production logistics park and focus on upgrading manufacturing logistics gathering area of the Economic Development Zone. Relying on business circle, plan and build business service logistics park, accelerate the construction and transformation of the modern warehouse logistics park.

\section{3) Manufacturing logistics and supply chain management project}

We should support construction of distribution facilities and logistics information platform and encourage socialization of logistics in industrial parks, encourage manufacturing enterprises to extend services for the upstream and downstream of supply chains, and build supply chain management platform. We should cultivate the fourth party logistics enterprise with supply chain design and consulting management ability, improve supply chain management services for equipment manufacturing enterprises and promote the integration of supply chain management [5].

\section{4) Agricultural products distribution project}

We should strengthen original cold storage building and establish a batch of cold storage of fruits and vegetables with pre-cooling and sorting processing facilities, low-temperature storage with closed platform and low temperature facilities. We should build a number of fresh agricultural products bases directly serving for surrounding cities, carry out construction pilot of cold chain logistics demonstration project, set up distribution and direct sales platform of agricultural products, actively expand the marketing channels of fresh agricultural products.

\section{5) "Internet plus" logistics supporting project}

Combined with construction of the national e-commerce model city, demonstration base, logistics park and commercial facilities, we should integrate distribution resources to build ecommerce logistics service platform and distribution network, build a logistics system which can effectively support the rapid development of e-commerce. We will accelerate the linkage and concentration of electricity supplier logistics, explore using high-speed rail resources to develop high-speed rail express, use existing bonded logistics parks to promote cross-border ecommerce pilot, improve a number of express delivery centers.

\section{Vigorously promote diversified innovation of logistics}

The diversified innovation of logistics involves not only innovation of logistics products and service contents, but also of the whole development environment of logistics [6]. In terms of Industrial structure, we should strengthen the concentration of logistics industry, develop the third and the fourth party logistics, pay attention to the interactive development of logistics industry and manufacturing industry, commercial trade, finance etc. In terms of infrastructure, we should accelerate the upgrading of logistics infrastructure, utilize logistics intelligent technology and automation equipment, strengthen optimization of logistics channel and logistics hub, and improve the level of logistics facilities application management. In terms of logistics subject, we should pay attention to integrate logistics resources, speed up the transformation of key logistics enterprises from logistics service providers to supply chain service providers, accelerate the separation of main and auxiliary manufacturing industry. In terms of top-level design of the logistics, we should liberalize market access, change the mode of supervision, and improve the coordination mechanisms.

\section{CONCLUSION}

In short, we should grasp the development opportunity of "the Belt and Road Initiatives" strategy, give full play to location and industrial advantages. Take construction of national regional logistics hub as the goal, promotion of industrial upgrading and transforming as the main line, we should optimize the layout of logistics space, establish an efficient, intensive and modern logistics system, accelerate to form a new pattern of modern logistics driven by the diversified innovation, such as service innovation, technological innovation and organizational innovation, etc. 


\section{ACKNOWLEDGMENT}

This work is supported by North Jiangsu Science and Technology Development Plan (Item No. BN2016016).The name of item is key technology integration of cold chain logistics of meat sheep in North Jiangsu based on O2O model.

\section{REFERENCES}

[1] Wang Wei, "Construct a new pattern of logistics industry development," J. Economic strategy research, vol.7, pp.45-47, 2015. (In Chinese)

[2] Wang Ming, "Three national strategies and opportunities for the development of logistics industry," J. China circulation economy, vol.7, pp.5-9, 2015. (In Chinese)

[3] Wei Jigang, "China logistics and long-term development strategy of," J. Chinese storage, vol.10, pp.35-39, 2015. (In Chinese)

[4] Cai Jin. "The pattern and direction of China's logistics industry," J. China logistics and purchasing, vol.11, pp.43-44, 2015. (In Chinese)

[5] He Liming. "Development trend and policy expectation of China's logistics supply chain under new normal condition," J. China circulation economy, vol.8, pp.4-8, 2014. (In Chinese)

[6] Ding Junfa. "New impetus, new opportunities and new models for the development of China's logistics industry," J. China circulation economy, vol.2, pp.9-15, 2014. (In Chinese) 